УДК: 81'373:070(477)(091)

DOI: https://doi.org/10.31470/2518-7600-2021-13-64-82

\title{
HISTORY OF STUDYING OF UKRAINIAN MASS MEDIA LANGUAGE
}

\section{ІСТОРІЯ ВИВЧЕННЯ МОВИ УКРАЇНСЬКОЇ ПРЕСИ}

\section{ИСТОРИЯ ИЗУЧЕНИЯ ЯЗЫКА УКРАИНСКОЙ ПРЕСЫ}

Юлія Калужинська,
кандидат філологічних наук,
старший викладач кафедри
документознавства та
методики навчання
kaluzhynskaya@gmail.com
orcid.org/ 0000-0002-9787-2686
Researcher ID AAE-7242-2020
Університет Григорія
Сковороди в Переяславі
вул. Сухомлинського 30,
м. Переяслав, Київська обл.,
08400

Yuliia Kaluzhynska, Ph.D. in Philological SciencesSenior Lecturer of Department of scientific discipline of documentation and teaching methods

kaluzhynskaya@gmail.com orcid.org/ 0000-0002-97872686

Researcher ID AAE-7242-2020 Hryhorii Skovoroda University in Pereiaslav 08401, Ukraine, Kyiv region, Pereiaslav, Sukhomlynskyi Str., 30

\section{ABSTRACT}

The article describes the historical stages of learning the language of the Ukrainian press. Attention to the language of journalism is due to the fact that the selection and use of language is characterized by a combination of two requirements - the desire to strengthen both the logical and emotional side of expression. The study of the language of journalism, namely the language of Ukrainian newspapers, has a history. The appearance of a significant number of articles on this topic was facilitated by language discussions on language culture, which in some way also affected the language of the press. 
In the 20 's of the $20^{\text {th }}$ century the language of the press stood out as a separate variety. It is determined that the basis of its development was the vernacular. It was found that the «newspaper language» developed in close connection with the language practice of the intelligentsia and influenced the prestige of the national language.

The language of the media is dynamic in nature, so it responds most quickly to all changes in public consciousness and reflects the state of the latter, influencing its formation. In the language of the media it is easy to see the new trends in approaches to language learning that can be traced in modern linguistics.

The role of the media in modern society is difficult to overestimate. They have a powerful potential for the state of public opinion, as most of their ideas about the world people get from newspapers and magazines. Characteristic features of the mass media are their publicity, i.e. an unlimited number of consumers; indirect, divided in space and time interaction of communicators; unidirectional influence from the communicator to the recipient, the impossibility of changing their roles

The study of the language of the media in recent years has also become particularly relevant. This is due to at least two factors: the situation of the functioning of literary language at the turn of the century and the priority for modern linguistics tendency to consider language material from a communicative standpoint, given the representation of language knowledge in human consciousness and patterns of language communication.

Keywords: press language, language culture, language means, historical aspects, newspaper language.

Problem statement: Globalization of mass information processes, emergence of audiovisual and electronic mass media has led to the fact that the center of literary language creation has moved to journalism, which today is an operational, dynamic, multi-accent carrier and producer of public opinion (Koval, 2011: 6). 
At the present stage, the role of the media has greatly increased. This is due to their close connection with the surrounding reality and sensitivity to social, economic, cultural, scientific and educational changes in the country and the world, as well as the main purpose - to respond to current events, facts and phenomena of today (Myslyva-Bunko, 2014: 25).

Preserving what is characteristic of the historical epoch as a whole, the language of journalistic style «best reflects the social practice of the people, the level of spiritual culture of society, its vital forces, the ability to self-preservation and renewal» (Serbenska, 1988: 22). It is the language of journalism that is a consistent expression of modern tendencies in the general literary norm and the most operative, intelligible and effective channel for the formation of people opinion.

A. P. Koval explains the increased attention to the language of journalism as follows: "Among the most functional styles, journalistic style is distinguished by the fact that the selection and use of language is characterized by a combination of both requirements - the desire to strengthen both the logical and emotional side of expression» (Koval, 2011: 80).

Analysis of recent publications: The study of the language of journalism, namely the language of Ukrainian newspapers, has a history. Thus, the emergence of a significant number of articles was facilitated by language discussions on language culture, which in some way affected the language of the press, sometimes it depended on the interest in the language of periodicals of individual scholars or research groups. The beginning of the last century was characterized by discussions about the speeches of I. NechuiLevytskyi «Modern journal language in Ukraine» (1907), «A crooked mirror of the Ukrainian language» (1912). The study of the Ukrainian «journal language», as well as «journal Ukrainian literature», began at the beginning of the last century with the works of I. Ya. Franko, B.D. Hrinchenko, I.S. Nechuy-Levytsky, L.S. Martovych and others. The language of the Ukrainian press (as, incidentally, the press itself), published since 1914, as well as 
between the two world wars in some parts of the Ukrainian lands, has not yet been the subject of a thorough study. There are only some remarks on this subject in the works of M.G. Sulyma, M.D. Hladkyi (Hladkyi, 1928: 273).

The language of Ukrainian periodicals in their works was considered by Andreichenko O. (Andreichenko, 2006), Barannyk D. (Barannyk, 1983), Gladky M. (Gladky, 1928), Koval T. (Koval, 2011), Navalna M. (Navalna, 2011).

The aim of the study. Carry out scientific processing of materials related to the study of the language of newspaper periodicals.

Presenting main material. The study of the language of newspapers and its audience in the 1920s was sociological and combined with linguistic observations, and the description of the language of the press was usually sociolinguistic. During this period, the language of the press was singled out as a separate variety, it was clearly defined that the basis of its development is the vernacular, a significant search for impulses for the development of the language of the press, establishing its role and place in the life of national languages. According to Yu. V. Shevelyov, the «newspaper language» develops in close connection with the language practice, first of all, of the intelligentsia, representing the «higher language», and significantly affects the prestige of the national language. The language of Ukrainian periodicals of the 50's is characterized by certain features, primarily due to the fact that the press is defined as part of the ideological structure, and language - as a means of its propaganda (Shevelyov, 2012).

The study of the language of the media in recent years has become particularly relevant. This is due to at least two factors: the situation of literary language at the turn of the century and the priority for modern linguistics tendency to consider language material from a communicative standpoint, given the representation of language knowledge in human consciousness and patterns of language communication (Zalipska, 2013). 
The language of the media is dynamic in nature, so it responds most quickly to all changes in public consciousness and reflects the state of the latter, influencing its formation. It is in the language of the media that it is easy to see new trends in approaches to language learning that can be traced in modern linguistics. Among such a special place is occupied by functional aspects of language use, they played an important role in the study of language in the late 20th century. (Alexandrova, 2000: 152).

The role of the media in modern society is difficult to overestimate. They have a powerful potential for the state of public opinion, as most of their ideas about the world people get from newspapers and magazines. Characteristic features of the mass media are their publicity, ie an unlimited number of consumers; indirect, divided in space and time interaction of communicators; unidirectional influence from the communicator to the recipient, the impossibility of changing their roles. At the same time, the mass media are created not only for the transmission of information, but also «themselves are active participants in socio-political and economic processes in society - participants who create situations, shape moods and thoughts». They implement the social control of the masses. An integral feature of the media - is their ability to influence the audience, the implementation of ideological, political, economic or organizational influence on the assessments, opinions and behavior of people.

The language of the media is characterized by a certain style of presentation of information. With the active development of the media (press, television, radio communications) there was a question of stylistic certainty of the language of public communication. D.H. Barannyk recognizes the language of the media as a separate functional style and notes the importance of tracing the typological features of the language of each of the types of media «in the direction of all components of the language structure: morphological, syntactic, lexical and phraseological» (Barannyk, 1983). 
Mass media is a phenomenon that is a generator of information, the material expression of which passes through language. That is why the media serve as a channel that can generate a new or deny the old system of language functioning, and thus dictate the boundaries of the culture of the Ukrainian word. The press was the first mass way to inform people. In the exploration «Nasha Gazetna Mova» M.M. Gladky described the state of the language of the central periodicals of 1927, the linguistic dynamics in comparison with 1925. The author records typical deviations in the language of newspapers, new words, states the patterns of language errors, their prevalence, disappearance, generation of new ones. Violations of the Ukrainian language are considered by the researcher at the syntactic and lexical levels. "A journalist must know the theory of his language well and master the mechanism of literary language, because otherwise his choice will be very limited, he will never get rid of the slavish attachment to the patterns of pathetic copying of other people's patterns, so-called language reflexes, and will never learn to write "simply», clearly and distinctly with the greatest savings of words and paper» (Gladky, 1928: 155).

According to M.V. Mamych, in addition to the concept of «language of mass communication», for the last 10-15 years another designation of the same object has spread - «language of mass media» (Mamych, 2016). Various researchers recognize that the latter - the object of media stylistics - the direction of functional stylistics in its communicative interpretation, which studies the patterns of functioning of the language of the media in connection with the content, purpose and situations of communication (Media Linguistics 2014); with the study of the peculiarities of the use of language tools that contribute to the effectiveness of media text, taking into account its diverse characteristics due to the hierarchy of extralingual factors. The most important approaches in media stylistics are - a) stylistic and typological, the subject of which is the laws of creation and functioning of media texts of different types and genres, due to the «updated» set of extralingual factors; b) 
functional and stylistic with its «conceptual and methodological universalism».

New, compared to linguistic-stylistic, is the emphasis on the fact that media stylistics expands the concept of journalistic style to the limits of mass communication = mass information. In 1999, O. A. Styshov called the language of the media the backbone of journalistic style (Styshov, 1999: 7). In the system of research of social communications in the first years of the 21 st century it is noted the formation of the direction «language of social communications $\rangle=\langle$ media linguistics $»$, preferring the second term (Kapeliushnyi, 2003: 264-265).

M.A. Zhovtobryukh covered the issue of the development of the language of the Ukrainian press in the monograph «The language of the Ukrainian press (until the mid-nineties of the 19th century)». The scientist defined the role of periodicals in the enrichment and standardization of the Ukrainian literary language its lexical structure, grammatical structure and spelling, in the creation of journalistic style (Zhovtobryukh, 1963). In the exploration «Language of the Ukrainian periodical press (late 19th early 20th centuries)» the author has already clarified the role of the periodical press in the history of the Ukrainian literary language, in the formation of its phonetic, orthographic, lexical, morphological, syntactic norms. in the formation and development of Ukrainian special terminology, in the stylistic enrichment of the language.

Since the 1960s, the study of the language of the Ukrainian press has developed in several directions. The first of them is normative and stylistic. Within this direction, the language of periodicals is studied in terms of how it meets the norms of literary language. In particular, O.A. Serbenska, analyzing the language of the press of the late twentieth century, makes an attempt at a systematic description and multifaceted analysis (linguistic, sociological, psychological) of the phenomena of journalistic speech as a certain aesthetic stereotype that depends on social factors (Serbenska, 2001). The researcher proved that the language of newspapers reflects trends in the development of general literary norms of the Ukrainian language. 
The second direction in the study of the language of the press, which is quite actively developing in Ukraine since the 70s of the 20th century, is related to the interpretation of the language of the newspaper as a special object. This is a functional and stylistic trend, represented by the works of such scientists as M.M. Pylynsky (Pylynsky, 1990), G.M. Sagach (Sagach, 1993) and others. Functional and stylistic approach involves the study of patterns and trends in the formation of intra-style forms, elucidation of the linguistic nature of the genre form, the search for aesthetic criteria of newspaper language.

In the mid-70's and early 80's of the 20th century the discussion of the language of the press unfolded among the authors of the monograph «The Language of Modern Mass Political Information» (1979). In addition, the object of analysis, more detailed or selective, newspaper language has always been when researchers have studied some facts of the Ukrainian language, raised issues of speech culture, etc..

A separate direction in the study of the language of Ukrainian newspapers - the history of the formation of the language of the Ukrainian press - was initiated by M.A. Zhovtobryukh and Yu. V. Shevelyov (Shevelyov, 2012). Various aspects of the current stage of language development of Ukrainian periodicals (periodicals of the $80 \mathrm{~s}-90 \mathrm{~s}$ of the XX century) were covered in the works of N.O. Boychenko (Boychenko, 2001), T.A. Kots (Kots, 1997), O.A. Styshov (Styshov, 2001) and others. An important place in the development of the theory of information style, the definition of its main features belongs to D.H. Barannyk (Barannyk, 1983), who paid much attention to the study of journalism in general.

In contrast to the research of O.S. Cheremskaya (Cheremskaya, 2002) and T.A. Kots (Kots, 1997), O.A. Styshov's monograph «Ukrainian vocabulary of the late XX century (based on the language of the media)» aims to study active processes in the development of vocabulary, semantics and word formation of the Ukrainian language (Styshov, 1999). The scientist outlines the main non-linguistic and intralinguistic factors that contributed to 
the intensification of qualitative and quantitative changes in the vocabulary of the national language, explores the main mechanisms of lexical nomination, indicative of the analyzed period. The paper defines the traditional definition of neologisms, clarifies the stages of their assimilation in language, analyzes the structural-semantic and stylistic function of occasionalisms in the linguistic practice of modern mass media.

O.I. Andreichenko describes vocabulary and phraseology in the texts of political discussions of the late 20th - early 21 st centuries. In her opinion, an indispensable component of the discussion is evaluative vocabulary and phraseology. The scholar notes that in modern political and polemical discourse there are certain metaphorical models that figuratively reproduce modern political life (Andreichenko, 2006).

T.G. Bondarenko (Bondarenok, 2003), as well as O.S. Cheremska (Cheremska, 2002), chose the language of local and regional newspapers, in particular those published in Cherkasy during 2000-2002, as material for the dissertation research. . The author has developed a typology of linguistic errors in printed publications, identifying and systematizing their features, as well as identified the foundations of linguistic theory, which explains the many anomorms recorded in journalistic materials, allows to adequately assess linguistic facts in terms of normative and nonnormative errors occur.

G.V. Shapovalova's research «Innovative processes in modern media text (functional-linguistic aspects)» is devoted to the language of the press (Shapovalova, 2003). The author researched innovative processes in the modern Ukrainian information text at the lexical level, in particular the tendency to update the vocabulary of mass media, the specifics of neologisms on the pages of printed publications and features of expressive speech as a tool of figurative thinking of journalists. According to G.V. Shapovalova, the language of the media, in particular its lexical base, is extremely sensitive to changes and external influences subsystem of the modern Ukrainian language, which is constantly evolving (Shapovalova, 2003: 5). 
Among the new research related to the media, in particular the press, we note the scientific studies of M.I. Navalna (Navalna, 2011). In the field of view of the researcher - lexical diffusion in the Ukrainian periodicals of the first decade of the XXI century. In the monograph the author analyzes the functional and stylistic use of emotionally colored lexical units and terminological vocabulary (economic, medical, sports, legal, etc.), functional and semantic manifestations of confessional vocabulary and stylistic potential of slang elements.

The media space of our country consists of many publications of various thematic areas, which try to occupy their niche in the system of informing the readership. In the conditions of fierce economic struggle, - as L.M. Gorodenko notes, - those editions which are able not only to find the information, but also to convey to readers the essence of a problem survive (Gorodenko, 2003).

Conclusions. Thus, the language of the press eventually emerged as an independent object of study, and today we can talk about media linguistics as a separate branch of stylistics, closely related to the philosophy of communication, sociology, the science of the basics of language culture.

Interest in the language of newspapers has been traced for a long time. The accents that scholars paid attention to changed, the approaches to the study of this concept changed, but one thing remained unchanged - the newspaper language has always influenced the culture of the language of the people and their consciousness.

\section{REFERENCES}

1. Aleksandrova, O. (2000). Kohnytyvnaia funktsyia iazyka v svete funktsyonalnoho podkhoda $\mathrm{k}$ eho izucheniiu [Cognitive function of language in the light of the functional approach to its study]. Kognitivnye aspekty iazykovoi kategorizacii: Sbornik nauchnykh trudov [Cognitive aspects of language categorization: a collection of scientific articles]. Riazan, 151-153 [in Russian]. 
2. Andreichenko, O. (2006). Leksyko-frazeolohichna osnova tekstiv politychnykh dyskusii (na materiali ukrainskoi presy kintsia XX - pochatku XXI stolittia) [Lexical and phraseological basis of texts of political discussions (on the material of the Ukrainian press of the end of the XX - the beginning of the XXI century)]. Candidate's thesis. Kyiiv [in Ukrainian].

3. Barannyk, D. (1983). Aktualni problemy doslidzhennia movy masovoi informatsii [Current problems of mass language research]. Movoznavstvo - Linguistics, 6, 13-17 [in Ukrainian].

4. Boychenko, N. (2001). Stiiki diieslivni spoluky u publitsystychnomu teksti: typolohichni oznaky ta ekspresyvnyi potentsial [Stable verb compounds in a journalistic text: typological features and expressive potential]. Candidate's thesis. Kyiiv [in Ukrainian].

5. Bondarenko, T. (2003). Typolohiia movnykh pomylok ta yikh usunennia pid chas redahuvannia zhurnalistskykh materialiv [Typology of language errors and their elimination when editing journalistic materials]. Extended abstract of candidate's thesis. Kyiiv [in Ukrainina].

6. Gladkyi, M. (1928). Nasha hazetna mova: Problema hazetnoi movy. Leksyka. Syntaksa. Frazeolohiia. Sut populiarnoho vykladu. Stylistyka yak pratsia hazetaria-zhurnalista [Our newspaper language: The problem of newspaper language. Vocabulary. Syntax. Phraseology. The essence of the popular presentation. Stylistics as the work of a journalist]. Kyiiv [in Ukrainian].

7. Gorodenko, L. (2003). Zasoby masovoi informatsii u konteksti hromadskoi dumky: formuvannia, funktsionuvannia, zhanrovi pryiomy [Mass media in the context of public opinion: formation, functioning, genre techniques]. Candidate's thesis. Kyiiv [in Ukrainian].

8. Duskaieva, L. Mediastylystyka: typolohycheskyi podkhod [Mediastilistics: a typological approach]. (n.d.) Retrieved from: https:// www.google.com.ua/ search?ie=UTF-8\&hl=ru\&q= Дускаева\%20 медиастилистика\&gws_rd=ssl\#hl=ru\&q=\%D0\% [in Russian]. 
9. Zhovtobriukh, M. (1970). Mova ukrainskoi periodychnoi presy (kinets XIX-poch. XX st.) [The language of the Ukrainian periodical press (end of the XIX - beginning of the XX century)]. Kyiiv: Nauk.dumka [in Ukrainian].

10. Zhovtobriukh, M. (1963). Mova ukrainskoi presy (do seredyny devianostykh rokiv XIX st.) [The language of the Ukrainian press (until the mid-nineties of the XIX century)]. Kyiiv: Vydavnyctvo AN URSR [in Ukrainian].

11. Zalipska, I. (2013). Komunikatyvni oznaky ukrainskoi movy $\mathrm{u}$ priamomu radio- $\mathrm{i}$ teleefiri [Communicative features of the Ukrainian language in live radio and television]. Candidate's thesis. Termopil [in Ukrainian].

12. Kapeliushnyi, A. (2003). Stylistyka. Redahuvannia zhurnalistskykh tekstiv: praktychni zaniattia [Stylistics. Editing journalistic texts: practical classes]. Lviv: IAIS [in Ukrainian].

13. Koval, T. (2011). Ekspresyvna funktsiia neolohizmiv u movi suchasnoho hazetnoho dyskursu [Expressive function of neologisms in the language of modern newspaper discourse], Naukovi zapysky. Seriia: Filologichni nauky (movoznavstvo) - Proceedings. Series: Philological Sciences (Linguistics), 100, 78-81 [in Ukrainian].

14. Koval, T. (2011). Zasoby ekspresyvizatsii ukrainskoho hazetnoho dyskursu pochatku XXI st [Means of expressionization of the Ukrainian newspaper discourse of the beginning of the XXI century]. Extended abstract of candidate's thesis. Herson [in Ukrainina].

15. Koz, T. (1997). Funktsionalnyi aspekt leksychnoi normy v zasobakh masovoi informatsii (na materiali hazet 90-kh rokiv XX stolittia) [Funktsionalnyi aspekt leksychnoi normy v zasobakh masovoi informatsii (na materiali hazet 90-kh rokiv $\mathrm{KhKh}$ stolittia)]. Extended abstract of candidate's thesis. Kyiiv [in Ukrainina].

16. Koz, T. (1997). Funktsionuvannia leksychnykh variantiv u zasobakh masovoi informatsii (na materiali hazet 90-kh rokiv) [Functioning of lexical variants in mass media (on the material of newspapers of the 90s)]. Movoznavstvo - Linguistics, 6, 56-63 [in Ukrainian]. 
17. Mamych, M. (2016). Linhvokultorolihchnyi kontent zhurnalu «Zhinka» (seredyna KhKh - pochatok KhKhI stolittia) [Linguocultural content of the magazine «Woman» (mid XX - early XXI century)]. Doctor's thesis [in Ukrainian].

18. Medialingvistyka: slovnyk terminiv ta poniat [Medialinguistics: the dictionaty of terms and meanings]. (2014). Kyiiv: VPC "Kyiivskyi universytet” [in Ukrainian].

19. Myslyva-Bunko, I. (2014). Skladni slova v movi suchasnoi ukrainskoi presy: struktura ta stylistychni funktsii [Complex words in the language of the modern Ukrainian press: structure and stylistic functions]. Candidate's thesis. Lutsk [in Ukrainian].

20. Navalna, M. (2011). Dynamika leksykonu ukrainskoi periodyky pochatku XXI st.: monografiya [Dynamics of the lexicon of Ukrainian periodicals of the beginning of the XXI century: monograph]. Kyiiv: Vydavnychyi dim Dmytra Burago, 328 [in Ukrainina].

21. Pylynskyi, M. (1990). Vzaiemodiia khudozhnoho $i$ publitsystychnoho styliv ukrainskoi movy [Interaction of artistic and journalistic styles of the Ukrainian language]. Kyiiv: Naukova dumka [in Ukrainian].

22. Sagach, G. (1993). Zolotosliv: navchalnyi posibnyk dlia serednii $i$ vyshchykh navchalnykh zakladiv [Zolotosliv: a textbook for secondary and higher education]. Kyiiv: Raiduga [in Ukrainian].

23. Serbenska, O. (1988). Mova hazety v aspekti sotsialnokulturnoho rozvytku suspilstva [The language of the newspaper in terms of socio-cultural development of society]. Movoznavstvo Linguistic, 4, 21-26 [in Ukrainian].

24. Serbenska, O. (2001). Innovatsii u movi suchasnykh ukrainskykh mas-media [Innovations in the language of modern Ukrainian mass media]. 125 rokiv naukovogo tovarystva imeni Shevchenka - 125 years of Shevchenko Scientific Society: a collection of scientific works and materials dedicated to the anniversary of the society, (pp. 158-177) [in Ukrainian 
25. Styshov, O. (2001). Okazionalizmy u movi suchasnykh masmedia [Occasionalisms in the language of modern mass media]. Kultura slova - Culture of the word, 59, 72-76 [in Ukrainian].

26. Styshov, O. (1999). Osoblyvosti rozvytku leksychnoho skladu ukrainskoi movy kintsia XX st [Features of the development of the lexical structure of the Ukrainian language of the late XX century]. Movoznavstvo - Linguistics, 1, 7-21 [in Ukrainian].

27. Cheremska, O. (2002). Leksychna ta hramatychna interferentsiia v suchasnii ukrainskii literaturnii movi yak naslidok ukrainsko-rosiiskoho bilinhvizmu (na materiali presy Kharkivshchyny 50-80-kh rokiv XX st.) [Lexical and grammatical interference in the modern Ukrainian literary language as a consequence of Ukrainian-Russian bilingualism (on the material of the Kharkiv region press of the $50-80$ s of the XX century)]. Extended abstract of candidate's thesis. Kharkiv [in Ukrainina].

28. Shapovalova, G. (2003). Innovatsiini protsesy v suchasnomu mediateksti (funktsionalno-linhvistychni aspekty) [Innovative processes in modern media text (functional-linguistic aspects)]. Extended abstract of candidate's thesis. Kyiiv [in Ukrainina].

29. Sheveliov, Yu. (2012). Narys suchasnoi ukrainskoi literaturnoi movy ta inshi linhvistychni studii [Essay on modern Ukrainian literary language and other linguistic studies]. Kyiiv: Tempora [in Ukrainian].

\section{ДЖЕРЕЛА ТА ЛІТЕРАТУРА}

1. Александрова О. Когнитивная функция языка в свете функционального подхода к его изучению. Когнитивные аспекты языковой категоризации: Сборник научных трудов. Рязань, 2000. С. 151-153.

2. Андрейченко О. Лексико-фразеологічна основа текстів політичних дискусій (на матеріалі української преси кінця XX - початку XXI століття): дис.... канд. філол. наук : 10.02.01. Київ, 2006. 285 с.

3. Баранник Д. Актуальні проблеми дослідження мови масової інформації. Мовознавство. Київ, 1983. Вип 6. С. 13-17 
4. Бойченко Н. Стійкі дієслівні сполуки у публіцистичному тексті: типологічні ознаки та експресивний потенціал : дис...... канд. філол. наук :т10.02.01. Київ, 2001. 192 с.

5. Бондаренко Т. Типологія мовних помилок та їх усунення під час редагування журналістських матеріалів : автореф. дис...... канд. філол. наук : 10.01.08. Київ, 2003. 20 с.

6. Гладкий М. Наша газетна мова: Проблема гезетної мови. Лексика. Синтакса. Фразеологія. Суть популярного викладу. Стилістика як праця газетаря-журналіста. Київ, 1928. 175 с

7. Городенко Л. Засоби масової інформації у контексті громадської думки: формування, функціонування, жанрові прийоми : автореф. дис...... канд. філол. наук : 10.01.08. Київ, 2003. $19 \mathrm{c}$

8. Дускаева Л. Медиастилистика: типологический подход URL : https://www.google.com.ua/search?ie=UTF-8\&hl=ru\&q= Дускаева $\% 20$ медиастилистика\&gws_rd=ssl\#hl=ru\&q=\%D0\%

9. Жовтобрюх М. Мова української періодичної преси (кінець XIX - поч. XX ст.). Київ : Наук. думка, 1970. 304 с.

10. Жовтобрюх М. Мова української преси (до середини дев'яностих років ХІХ ст.). Київ : Вид-во АН УРСР, 1963. 415 с.

11. Заліпська I. Комунікативні ознаки української мови у прямому радіо- і телеефірі : дис....... канд. філол. наук : 10.02.01. Тернопіль, 2013. $351 \mathrm{c}$

12. Капелюшний А. Стилістика. Редагування журналістських текстів : практичні заняття : навч. посіб. з курсів: «Практична стилістика української мови», «Стилістика тексту», «Редагування в засобах масової інформації». Львів : IAIC, 2003. $544 \mathrm{c}$

13. Коваль Т. Експресивна функція неологізмів у мові сучасного газетного дискурсу. Наукові записки. Серія : Філологічні науки (мовознавство) : зб. наук. праць. Кіровоград : РВВ КДПУ ім. В. Винниченка, 2011. Вип. 100. С. 78-81

14. Коваль Т. Засоби експресивізації українського газетного дискурсу початку XXI ст. : автореф. дис...... канд. філол. наук : спец. 10.02.01. Херсон, 2011. 20 с. 
15. Коць Т. Функціональний аспект лексичної норми в засобах масової інформації (на матеріалі газет 90-х років XX століття) : автореф. дис.......канд. філолог. наук : 10.02.01. Київ, 1997. 16 с.

16. Коць Т. Функціонування лексичних варіантів у засобах масової інформації (на матеріалі газет 90-х років). Мовознавство. 1997. Вип. 6. С. 56-63.

17. Мамич М. Лінгвокульторолігчний контент журналу «Жінка» (середина XX - початок XXI століття) : дис....... докт. філол. наук : 10.02.01. Київ, 2016. 399 с

18. Медіалінгвістика : словник термінів і понять / Л. І. Шевченко, Д. В. Дергач, Д. Ю. Сизонов / за ред. Л. І. Шевченко. Київ : ВПЦ «Київський університет”, 2014. 380 c.

19. Мислива-Бунько I. Складні слова в мові сучасної української преси: структура та стилістичні функції : дис...... канд. філол. наук : 10.02.01. Луцьк, 2014. 276 с.

20. Навальна М. Динаміка лексикону української періодики початку XXI ст. Монографія. Київ : Видавничий дім Дмитра Бураго, 2011. 328 с.

21. Пилинський М. Взаємодія художнього і публіцистичного стилів української мови. Київ : «Наукова думка», 1990. 216 с.

22. Сагач Г. Золотослів : навчальний посібник для середній i вищих навчальних закладів. Київ : Райдуга, 1993. 378 с.

23. Сербенська О. Мова газети в аспекті соціальнокультурного розвитку суспільства. Мовознавство. 1988. Вип 4. C. 21-26.

24. Сербенська О. Інновації у мові сучасних українських масмедіа. 125 років Наукового товариства імені Шевченка : зб. наук. пр. і матеріалів, присвячений ювілею товариства. Львів, 2001. С. $158-177$.

25. Стишов О. Оказіоналізми у мові сучасних мас-медіа. Культура слова. Київ, 2001. Вип. 59. С. 72-76.

26. Стишов О. Особливості розвитку лексичного складу української мови кінця ХХ ст. Мовознавство. 1999. Вип. 1. C. 7-21. 
27. Черемська О. Лексична та граматична інтерференція в сучасній українській літературній мові як наслідок українськоросійського білінгвізму (на матеріалі преси Харківщини 50-80-х років XX ст.) : автореф. дис..... канд. філол. наук : 10.02.01. Харків, 2002. 16 с.

28. Шаповалова Г. В. Інноваційні процеси в сучасному медіатексті (функціонально-лінгвістичні аспекти) : автореф. дис...... канд. філол. наук : 10.01.08. Київ, 2003. 20 с.

29. Шевельов Ю. Нарис сучасної української літературної мови та інші лінгвістичні студії. Київ : Темпора, 2012. 446 с.

\section{АНОТАЦІЯ}

Стаття описує історичні етапи вивчення мови украӥнської преси. Увага до мови публіцистики зумовлена тим, щзо добір і використання мовних засобів характеризується поєднанням в ній двох вимог - прагненням до посилення як логічного, так і емоційного боку висловлювання. Дослідження мови публіцистики, а саме мови украӥнських газет, має свою історію. Появі значної кількості статей у изй тематиці сприяли мовні дискусї з питань культури мови, які певним чином торкалися й мови преси.

У 20-х роках XIX ст. мова преси виокремилась як окремий різновид. Визначено, щзо основою ї̈ розвитку була народна мова. Виявлено, щуо «газетна мова» розвивалась в тісному зв'язку з мовною практикою тогочасної інтелігениії та впливала на престиж національної мови.

Мова засобів масової інформачії є динамічною за своєю суттю, тому вона найшвидше реагує на всі зміни в суспільній свідомості та відображає стан останньої, впливаючи на ї̈ формування. Саме в мові мас-медіа легко побачити нові тенденції в підходах до вивчення мови, які простежуються в сучасній лінгвістиці.

Роль засобів масової інформацї в сучасному суспільстві важко переоцінити. Вони мають потужний впливовий потенціал на стан суспільної думки, оскільки більшість своӥх 
уявлень про світ людина отримує з газет $i$ журналів. Характерні риси мас-медіа - $\ddot{і х ~ п у б л і ч н і с т ь, ~ п о б т о ~}$ необмежене коло споживачів; непряма, розділена у просторі $i$ часі взаємодія комунікантів; односпрямованість впливу від комунікатора до реиипієнта, неможливість зміни їх ролей.

Вивчення мови засобів масової інформаці в останні роки набуло також особливої актуальності. Це зумовлено принаймні двома факторами: ситуацією функиіонування літературної мови на рубежі століть і пріоритетною для сучасної лінгвістики тенденцією розглядати мовний матеріал з комунікативних позицій, з огляду на репрезентацію знання мови у свідомості людини $i$ закономірності мовного спілкування.

Ключові слова: мова преси, культура мови, мовні засоби, історичні аспекти, газетна мова.

\section{АННОТАЦИЯ}

Статья описывает исторические этапь изучения языка украинской прессы. Внимание к языку публицистики обусловлено тем, что отбор и использование языковых средств характеризуется сочетанием в нем двух требованийстремлением кусилению как логической, так и эмоччиональной стороны выражения. Исследование языка публицистики, а именно языка украинских газет имеет свою историю. Появлению значительного количества статей в этой тематике способствовали языковые дискуссии по культуре языка, которые определенным образом затрагивали и язык npeccbl.

В 20-х годах XIX ст. язык прессы выделился как отдельная разновидность. Определено, что основой ее развития был народный язык. Выявлено, что "газетная речь" развивалась в тесной связи с языковой практикой интеллигенциии того времени и влияла на престиж нациионального языка. 
Язык средств массовой информации динамичен по своей сути, поэтому он быстрее всего реагирует на все изменения в общественном сознании и отражает состояние последнего, влияя на его формирование. Именно в языке СМИ легко увидеть новые тенденции в подходах к изучению языка, которые прослеживаются в современной лингвистике.

Роль средств массовой информации в современном обществе сложно переоценить. Они обладают мощуным влиятельным потенциалом на состояние общуественного мнения, поскольку большинство своих представлений о мире человек получает из газет и журналов. Характерные черть масс-медиа - их публичность, то есть неограниченный круг потребителей; косвенное, разделенное в пространстве и времени взаимодействие коммуникантов; однонаправленность воздействия от коммуникатора к реципиенту, невозможность смены их ролей.

Изучение языка средств массовой информации в последние годь приобрело также особую актуальность. Это обусловлено, по крайней мере, двумя факторами: ситуацией функиионирования литературного языка на рубеже веков и приоритетной для современной лингвистики тенденцичей рассматривать языковой материал с коммуникативных позиций, учитывая репрезентацию знания языка в сознании человека и закономерности речевого общения.

Ключевые слова: язык прессы, культура языка, языковые средства, исторические аспекты, газетный язык. 